\title{
Applying Sustainable Tourism Indicators to Community-Based Ecotourism Ventures in Southern Africa
}

\author{
By Kevin Mearns*
}

\begin{abstract}
Tourism has been proposed as the panacea for many of the problems of the developing world and has been seen as a potential solution to ensure the long-term protection of natural resources and as a means of satisfying the needs of the poor communities in close proximity to protected areas. Community-based ecotourism (CBE), a very specific form of tourism, focuses on initiatives that are not only environmentally sensitive, but aim to give community members a high degree of control over tourism and ensure that a significant portion of benefits accrue to them. Many CBE ventures have been plagued by many challenges in the past and have been unsustainable and as a result ceased to operation. This study applies a framework of sustainability indicators to a number of CBE ventures across southern Africa, in an attempt to ascertain areas of concern and potential threats to the long-term sustainability of these operations.
\end{abstract}

Keywords: Community-based ecotourism, Southern Africa, Sustainable tourism indicators.

\section{Introduction}

Community-based ecotourism (CBE) has been advocated by many (Fennell 2003, Magakgala 2003, Mogome 2003, Scheyvens 1999, The International Ecotourism Society 2015) as one of the potential solutions to the economic development of rural impoverished communities which have natural resource assets which could be sustainably utilised for the economic development of these peripheral communities. Ecotourism is defined as "responsible travel to natural areas that conserves the environment and improves the well-being of local people" (The International Ecotourism Society 2015). CBE therefore implies that communities have substantial control over and involvement in the tourism project and that the largest portion of the benefits remain within the community (Epler Wood 2002). Tourism is seen as an important mechanism for local communities to benefit from protected areas, however these ventures need to manage their environmental impacts, their economic viability and social partnerships and environment very carefully to ensure that tourism does not become a self-destructive process that destroys the resources it is based upon. Major concerns have been raised regarding the ineffectiveness, potential unsustainability and the failure of community-based ecotourism ventures (Dixey 2008). In turn the success and sustainability of community-based ecotourism ventures have not been greatly

*Professor, Department of Environmental Sciences, University of South Africa, South Africa. 
researched (Goodwin and Santilli 2009). In an attempt to address these concerns this study has applied an evaluation framework making use of sustainable tourism indicators to determine the sustainability performance of a number of CBE ventures in southern Africa. This study forms part of a larger study (Mearns 2010), focussing on the development of an evaluation framework using sustainable tourism indicators to determine the sustainability of $\mathrm{CBE}$ ventures in southern Africa.

\section{Sustainable Indicator use in Tourism}

Hart (2015: 1) defines indicators as "something that helps you understand where you are, which way you are going and how far you are from where you want to be". Indicators have the ability to reduce large quantities of information into a simpler form, without losing the critical information. Indicators summarize relevant information to create clearly evident phenomena of interest. Sustainability indicators deliver meaning that extends beyond the attributes directly associated with the datasets, conversely statistics merely provides raw data with no meaning.

The United Nations World Tourism Organisation (WTO) developed the use of sustainability indicators to help tourism managers obtain and use information to better support decision making towards increased sustainability in tourism. Indicators are the building blocks toward sustainable tourism and are intended to be used as tools that assist managers to respond to important issues. The WTO (2004: 8) explains that indicators are measures severity of current issues, signals of upcoming problems and measures of risk. Indicators are a means to identify and monitor the results of actions. Indicators are information sets which are used on a regular basis to measure important changes of tourism developments and management actions. They can measure: a) changes in tourism's own structures and internal factors, b) changes in external factors which affect tourism and c) the impacts caused by tourism. Both qualitative and quantitative information can be used for sustainability indicators. If indicators are used properly they can become important management tools or performance measures which can supply essential information to managers and other stakeholders in tourism. "Good indicators can provide in-time information to deal with pressing issues and help guide the sustainable development of a destination" (WTO 2007: 4).

As tourists become more aware of their impacts on the environment, they are demanding more sustainable tourism experiences (Okech 2009). These changing market trends, together with the devolution of natural resource management rights and responsibilities from the state to communities, has placed communities in a very favourable position to harness their natural and cultural assets to capitalize on the growing visitor arrivals and receipts in order to alleviate poverty within rural communities. These $\mathrm{CBE}$ ventures can only be successful and sustainable if the three primary elements, community, conservation and tourism, are managed effectively. 


\section{Compilation of the Evaluation Framework}

The sustainability indicator framework was developed in a top-down approach in order to provide a cost-and-time effective means for monitoring the economic, social and environmental sustainability of CBE ventures. According to the WTO (2004) and Keyser (2009), indicators are seen as the core element in operationalizing sustainability. The use of sustainability indicators provides an objective way of measuring and monitoring sustainability. Before selecting the indicators that were used in the evaluation framework, two important questions needed to be addressed:

How Many Indicators Should Be Selected?

Clearly there is no ideal number of indicators to use. Any attempt to address all the aspects of sustainability using too few indicators would leave important gaps, while selecting too many indicators in turn could overwhelm users and the collection of data could become too complex and time-consuming. According to the WTO (2004: 41) "most practitioners agree that it is essential to prioritize issues and the indicators that correspond to them, to help create a shorter list". "Practitioners agree 12 to 24 indicators are optimal" (WTO 2004: 42).

\section{Which Issues Do the Selected Indicators Need to Address?}

Important issues that need to be addressed in this investigation relate to the three core issues of CBE, namely community, tourism and conservation. Each of these issues could be linked to the triple bottom line of sustainability reporting namely social, economic and environmental sustainability, or otherwise stated as people, profit and planet. Community links to social sustainability, tourism links to the economic sustainability and conservation links to environmental sustainability.

The World Tourism Organization (2004) identified 12 baseline issues which served as an important point of departure for the identification of indicators. The list of baseline indicators covers a range of economic, social and environmental issues likely to be found in most destinations. As the baseline issues and indicators leave gaps with respect to CBE nature of this investigation, it was important to include additional issues and indicators which relate specifically to community-based ecotourism. Additional issues and indicators relating to education, community decision making, community benefits, culture, biodiversity and conservation as well as networking and collaboration were included.

Eighteen issues with 34 associated indicators were selected for the evaluation framework. Each of these indicators required a specific data collection method in order to establish the performance with respect to each specific indicator. The identified issues and associated indicators are listed in Table 1. The research used a multiple case study mixed method research design. A variety of data collection instruments were used for the collection of the data with respect to the listed sustainability issues and indicators. These ranged from questionnaires and interviews, direct observations and photographic records, field notes, secondary 
data, water sampling and analysis and data collected using a global positioning system. The results obtained from these data collection methods were utilized in combination to arrive at results.

Table 1. Evaluation Framework Listing the Selected Issues and Indicators

\begin{tabular}{|c|c|}
\hline Issue & Indicator \\
\hline Social issues & Social indicators \\
\hline \multirow{2}{*}{$\begin{array}{l}\text { 1. Local satisfaction with } \\
\text { tourism }\end{array}$} & 1.1 Local satisfaction level with tourism \\
\hline & 1.2 Local community complaints \\
\hline \multirow[t]{2}{*}{$\begin{array}{l}\text { 2. Effects of tourism on } \\
\text { communities }\end{array}$} & $\begin{array}{l}\text { 2.1 Percentage who believe that tourism has helped bring } \\
\text { new services or infrastructure }\end{array}$ \\
\hline & 2.2 Other effects of tourism on the community \\
\hline \multirow[t]{3}{*}{ 3. Education } & 3.1 Education of tourists \\
\hline & 3.2 Education of community \\
\hline & 3.3 Training and skills development of staff members \\
\hline 4. Community decision making & 4.1 Community decision-making structures \\
\hline 5. Community benefits & 5.1 Community benefits from tourism \\
\hline 6. Culture & 6.1 Cultural appreciation and conservation \\
\hline Economic issues & Economic indicators \\
\hline \multirow[t]{5}{*}{ 7. Sustaining tourist satisfaction } & 7.1 Level of tourist satisfaction \\
\hline & 7.2 Perception of value for money \\
\hline & 7.3 Percentage of return visitors \\
\hline & 7.4 Perception of sustainability \\
\hline & 7.5 Tourist complaints \\
\hline \multirow[t]{3}{*}{ 8. Tourism seasonality } & 8.1 Tourist arrivals by month \\
\hline & 8.2 Occupancy rates for accommodation by month \\
\hline & $\begin{array}{l}\text { 8.3 Percentage of tourist industry jobs which are permanent or } \\
\text { full time (compared to temporary/seasonal jobs) }\end{array}$ \\
\hline \multirow[t]{3}{*}{ 9. Economic benefits of tourism } & $\begin{array}{l}\text { 9.1 Number of local people (and ratio of men to women) } \\
\text { employed in tourism }\end{array}$ \\
\hline & 9.2 Revenue generated \\
\hline & 9.3 Revenue spent in area \\
\hline Environmental issues & Environmental indicators \\
\hline \multirow[t]{3}{*}{ 10. Energy management } & 10.1 Per capita energy consumption (per person day) \\
\hline & 10.2 Energy-saving measures \\
\hline & $\begin{array}{l}10.3 \text { Percentage of energy consumption from renewable } \\
\text { resources }\end{array}$ \\
\hline \multirow[t]{2}{*}{$\begin{array}{l}\text { 11. Water availability and } \\
\text { conservation }\end{array}$} & $\begin{array}{l}11.1 \text { Water use (total water volume consumed and litres } \\
\text { per tourist per day) }\end{array}$ \\
\hline & 11.2 Water conservation measures \\
\hline 12. Drinking water quality & 12.1 Water treated to international potable standards \\
\hline 13. Sewage treatment & 13.1 Sewage treatment systems \\
\hline \multirow[t]{2}{*}{ 14. Solid waste management } & 14.1 Waste volume produced \\
\hline & 14.2 Waste disposal (landfill, recycling, etc.) \\
\hline 15. Controlling use intensity & 15.1 Number of tourists per square metre of the site \\
\hline 16. Biodiversity and conservation & $\begin{array}{l}\text { 16.1 Local community involvement in conservation } \\
\text { projects in area }\end{array}$ \\
\hline Crosscutting issues & Crosscutting indicators \\
\hline 17. Development controls & $\begin{array}{l}\text { 17.1 Existence of a development planning process } \\
\text { including tourism }\end{array}$ \\
\hline 18. Networking and collaboration & 18.1 Partnerships and collaborations \\
\hline
\end{tabular}

Source: WTO 2004 and Author's estimations. 


\section{Selection of Case Studies}

During an assessment of the status of natural resource-based community tourism in the SADC region, Johnson (2001) describes six types of CBE in southern Africa (Table 2). The aim of this study was to use the evaluation framework on six representative samples of these 6 types.

Table 2. Types of Community-Based Ecotourism 1. Operations owned and managed by entrepreneurs from communities

A local entrepreneur from the community has taken an opportunity that has presented itself. Such an opportunity may have arisen as a spin-off from a nearby conventional tourism attraction or operation such as a national park or game reserve or an existing tourism establishment.

2. Operations wholly owned and managed by communities

The community owns and manages the operation entirely, without significant outside assistance. The operation may be run by an informal grouping of community members or it may be a formally elected or appointed committee, trust, association or even a formally registered company.

3. Operations run through informal agreements between private sector operators and communities

This type of CBE venture involves some form of agreement or arrangement between a private sector operator and a community that has some form of tourism product, service or resource to offer tourists.

4. Operations run through formal agreements between private sector operators and communities

This form of CBE is similar to the previous type but in this case it involves a partnership that has been formalized through the signing of formal business agreements and contracts between the two parties.

5. Operational partnerships between state, private sector operators and communities

A three-way partnership exists between the state, the private sector and the community. This type of CBE will also be referred to as a triple joint venture.

6. Operations run by organizations such as national trusts or societies

This form of operation is run by an existing national trust or society. These organizations are usually closely allied with conservation interests or wildlife protection. In this case, however, the "community" may be defined as the members of the trust or the society. Sometimes the community may also include all the citizens of a particular country.

Source: Johnson 2001.

Although these six categories may be used as a means for classifying all CBE ventures, it is important to note that these six types are generalizations and combinations of the types may exist. Using an inventory of 331 community-based ecotourism ventures compiled by Mearns (2010) telephonic interviews were conducted with these ventures to determine which of these ventures may be catergorised as Community-based Ecotourism ventures. The resultant 44 ventures were then classified into the abovementioned 6 types and a random selection within each type was done to select the 6 case studies for further investigation. 
The final cases selected were:

- Individually owned: Aba-Huab Campsite.

- Community owned: Kaziikini \& Shandreka.

- Informal joint venture: Malealea Lodge.

- Formal joint venture: Damaraland Camp.

- Triple joint venture: Tembe Lodge.

- Organization run: !Khwa ttu.

\section{Selected Results Emanating from the Cross-Case Analysis}

The results of each issue and indicator were tabulated to facilitate comparison across cases. In each table the results pertaining to all six case studies are included. Only one random example of each a social, economic and an environmental issue and indicator are provided here as an illustration of the results that emanated from the application of the evaluation framework. The reason for this being that the results are too detailed to include in this paper. The randomly selected issues and indicators for a more detailed discussion are Issue 4: Community decision-making; Indicator 4.1: Community decisionmaking structures, Issue 7: Sustaining tourism satisfaction; Indicator 7.1: level of tourist satisfaction, Issue 10: Energy management; Indicator: 10.1: Per capita energy consumption (per person per day). Abbreviations are used to indicate the source of the data from interviews and questionnaires (SI - Staff interviews, CI - Community interviews, VQ - Visitor questionnaires). Before the cross-case analysis was conducted, the resultant responses (where appropriate) were colour coded in order to aid the discussion of the results as indicated in Table 3. A differentiation has also been made between the positively and the negatively stated questions. In order to differentiate between positive and negative statements an example is given from Issue 1: Local satisfaction with tourism. An example of a positive statement is "Is tourism good for the community?" while an example of a negative statement is "Is there anything that bothers you about tourism in your community?" All negatively stated questions are indicated with a "-ve" (Table 5).

Table 3. Colour Coding Categories of Selected Responses to Aid Analysis

\begin{tabular}{|l|c|c|c|c|}
\hline Colour coding & $\begin{array}{c}\% \text { responses } \\
\text { (positive } \\
\text { statements) }\end{array}$ & $\begin{array}{c}\% \text { responses } \\
\text { (negative } \\
\text { statements) }\end{array}$ & $\begin{array}{c}\text { Cumulative Likert } \\
\text { scale results } \\
\text { (positively stated) }\end{array}$ & $\begin{array}{c}\text { Cumulative Likert } \\
\text { scale results (negatively } \\
\text { stated) }\end{array}$ \\
\hline Excellent & $81-100$ & $0-20$ & $4.21-5.0$ & $1.0-1.8$ \\
\hline Good & $61-80$ & $21-40$ & $3.41-4.2$ & $1.81-2.6$ \\
\hline Average & $41-60$ & $41-60$ & $2.61-3.4$ & $2.61-3.4$ \\
\hline Below average & $21-40$ & $61-80$ & $1.81-2.6$ & $3.41-4.2$ \\
\hline $\begin{array}{l}\text { Cause for } \\
\text { concern }\end{array}$ & $0-20$ & $81-100$ & $1.0-1.8$ & $4.21-5.0$ \\
\hline
\end{tabular}

Source: Author's estimations. 


\section{Cross-Case Analysis of a Selected Social Issue}

\section{Issue 4: Community Decision Making}

In this case the staff and community members' perceptions of the level of community control over tourism were tested (Table 4).

\section{Indicator 4.1: Community Decision-Making Structures}

As could be expected, the responses from the three ventures where the community had the greatest say in decision making (Kaziikini, Damaraland Camp and !Khwa ttu) received the highest responses from both staff and community members interviewed, while the staff and community members interviewed at Tembe Lodge (triple joint venture) and Malealea Lodge (informal joint venture) indicated that the community had low levels of control over tourism at these two establishments. At Malealea the tourism activities at the Lodge are controlled by the owner of the Lodge while the community only have control over the pony-trekking portion of the operation. However, at Tembe Lodge the community as an equal partner in the Lodge is dominated by the private sector partner and the Conservation Authority which have a much greater influence over the operations at Tembe Lodge. The staff at Aba-Huab indicated that the community has a high level of control over tourism while the community indicated the opposite. This could be explained by the fact that the staff members were aware that the owner of the Campsite was also a member of the Conservancy and had to report to the Conservancy membership. This may explain the higher level of responses from staff members. Since the community members interviewed at Aba-Huab were not part of the Conservancy membership they might have felt that the community (which in their case might have referred to the non-conservancy members of the community neighbouring the Aba-Huab Campsite) might have very little control over tourism in the area. 
Table 4. Summary of Cross-Case Responses Relating to Issue 4: Community Decision Issue; 4.1: Community Decision Making Structures (SI=Staff

Interviews, $C I=$ Community Interviews)

\begin{tabular}{|c|c|c|c|c|c|c|c|c|c|c|c|c|c|}
\hline \multirow{2}{*}{\multicolumn{2}{|c|}{\begin{tabular}{l|} 
Issue 4: \\
Community \\
decision making
\end{tabular}}} & \multicolumn{2}{|c|}{$\begin{array}{c}\text { Individually } \\
\text { operated }\end{array}$} & \multicolumn{2}{|c|}{$\begin{array}{c}\text { Community } \\
\text {-operated }\end{array}$} & \multicolumn{2}{|c|}{$\begin{array}{c}\text { Informal } \\
\text { joint } \\
\text { venture }\end{array}$} & \multicolumn{2}{|c|}{$\begin{array}{c}\text { Formal } \\
\text { joint } \\
\text { venture }\end{array}$} & \multicolumn{2}{|c|}{$\begin{array}{c}\text { Triple } \\
\text { joint } \\
\text { venture }\end{array}$} & \multicolumn{2}{|c|}{$\begin{array}{c}\text { Organ. } \\
\text { operated }\end{array}$} \\
\hline & & \multicolumn{2}{|c|}{$\begin{array}{c}\text { Aba-Huab } \\
\text { Campsite }\end{array}$} & \multicolumn{2}{|c|}{$\begin{array}{l}\text { Kaziikini \& } \\
\text { Shandreka }\end{array}$} & \multicolumn{2}{|c|}{$\begin{array}{c}\text { Malealea } \\
\text { Lodge }\end{array}$} & \multicolumn{2}{|c|}{$\begin{array}{c}\text { Damaraland } \\
\text { Camp }\end{array}$} & \multicolumn{2}{|c|}{$\begin{array}{l}\text { Tembe } \\
\text { Lodge }\end{array}$} & \multicolumn{2}{|c|}{ !Khwa ttu } \\
\hline \multicolumn{14}{|c|}{ 4.1 Community decision-making structures } \\
\hline $\begin{array}{l}\text { Staff and } \\
\text { community } \\
\text { responses }\end{array}$ & & SI & CI & SI & CI & SI & CI & SI & CI & SI & CI & SI & CI \\
\hline $\begin{array}{l}\text { Does the } \\
\text { community have } \\
\text { control over } \\
\text { tourism? }\end{array}$ & $\begin{array}{c}\% \\
\text { yes }\end{array}$ & 70 & 16.7 & 100 & 100 & 40 & 60 & 90 & 80 & 30 & 20 & 90 & 100 \\
\hline $\begin{array}{l}\text { Does tourism } \\
\text { create jobs for } \\
\text { local people? }\end{array}$ & $\begin{array}{c}\% \\
\text { yes }\end{array}$ & 90 & 100 & 100 & 100 & 100 & 100 & 100 & 60 & 100 & 100 & 90 & 60 \\
\hline $\begin{array}{l}\text { Does the money } \\
\text { spent by tourists } \\
\text { remain in the } \\
\text { community? }\end{array}$ & $\begin{array}{c}\% \\
\text { yes }\end{array}$ & 20 & 33.3 & 100 & 100 & 80 & 100 & 90 & 40 & 20 & 0 & 80 & 100 \\
\hline
\end{tabular}

Source: Author's estimations.

\section{Cross-Case Analysis of a Selected Economic Issue}

Issue 7: Sustaining Tourism Satisfaction

The satisfaction of the tourists visiting the tourism venture is very important as it is the most important aspect in terms of the economic viability of a tourism venture (Table 5). If the tourists have a good experience when visiting a tourism venture the possibility exists that they will not only return as visitors but that they will act as important agents for word of mouth marketing to other potential visitors.

Indicator 7.1: Level of Tourist Satisfaction

This indicator measures the level of tourism satisfaction in terms of five sub-fields or sub-areas: enjoyment, access, environment, service and safety. The results of each of these five sub-fields will be discussed separately.

- The visitors' perceptions of enjoyment rated all six CBE ventures as ranging from good to excellent. This indicates that the visitors enjoyed the experiences they had at the six cases.

- The visitors' perception regarding access was generally very good, with the exception of the question relating to the state of the roads. Four of the six cases studies received an average rating for the state of the roads. Many of the roads were dirt roads and they were in a very poor condition. The state of the roads is presently not perceived as a major obstacle for the tourism ventures as the state of the roads is often also 
part of the adventure and exploration element of the CBE ventures, drawing tourists who prefer the rugged, untamed environment and the particular offerings of these ventures. The signage at Malealea Lodge (informal joint venture), which was in a very poor state and needed to be replaced or renewed urgently, also received a lower score than the others in the area.

- With regard to the environmental indicators, all the stated questions received good to excellent responses; only one exception is clearly evident in Table 5. The noise levels at Kaziikini Campsite (communityoperated) were very disturbing to a number of visitors who visited the area for peace and tranquility. The disturbance was caused by a number of visitors who were intoxicated in the evenings preceding and during the research. Since the camp staff members were unable to control the noise levels of these visitors, Kaziikini Campsite received a low score. The ability of the staff members to control the visitors with respect to their conduct is important as it may lead to a high level of dissatisfaction if this kind of behaviour is allowed to take place unchecked.

- The level of service received a high score from the visitors. The only aspect that needed to be attended to was the quality of the cuisine at Aba-Huab Campsite (individually operated) and Kaziikini Campsite (community-operated) which received a very average score.

- As far as safety and security was concerned, the visitors all perceived the ventures as safe and secure. 
Table 5. Summary of Cross-Case Responses Relating to Issue 7: Sustaining Tourist Satisfaction; Issue 7.1: Level of Tourist Satisfaction (VQ=Visitor Questionnaires)

\begin{tabular}{|c|c|c|c|c|c|c|c|}
\hline \multirow{2}{*}{\multicolumn{2}{|c|}{ Issue 7: Sustaining tourist satisfaction }} & 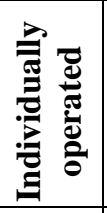 & 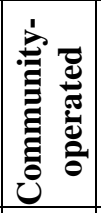 & 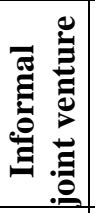 & 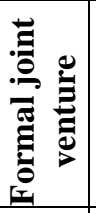 & 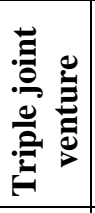 & 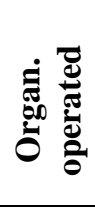 \\
\hline & & 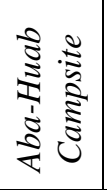 & 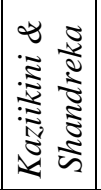 & 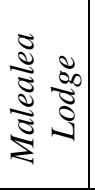 & 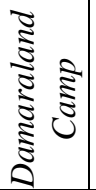 & $\begin{array}{l}0 \\
0 \\
0 \\
0 \\
0 \\
0 \\
0 \\
0 \\
0\end{array}$ & 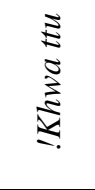 \\
\hline \multicolumn{8}{|l|}{ 7.1 Level of tourist satisfaction } \\
\hline \multicolumn{2}{|l|}{ Visitor responses } & VQ & VQ & VQ & VQ & VQ & VQ \\
\hline \multicolumn{8}{|l|}{\begin{tabular}{|l|} 
Enjoyment sub-indicators \\
\end{tabular}} \\
\hline I enjoyed my experience & $\begin{array}{l}\text { Ave. Likert } \\
\text { score }\end{array}$ & 4.1 & 4.55 & 4.7 & 5 & 4.7 & 4.67 \\
\hline $\begin{array}{l}\text { [Destination] provided a good variety of } \\
\text { experiences }\end{array}$ & $\begin{array}{l}\text { Ave. Likert } \\
\text { score }\end{array}$ & 3.5 & 3.67 & 4.2 & 4.1 & 4.4 & 4 \\
\hline $\begin{array}{l}\text { I would recom-mend [destination] to my } \\
\text { friends }\end{array}$ & $\begin{array}{l}\text { Ave. Likert } \\
\text { score }\end{array}$ & 4.5 & 4.45 & 4.9 & 4.7 & 4.7 & 4.42 \\
\hline \multicolumn{8}{|l|}{ Access sub-indicators } \\
\hline The state of the roads made travel easy & $\begin{array}{l}\text { Ave. Likert } \\
\text { score }\end{array}$ & 3.3 & 3.36 & 2.6 & 3 & 4.2 & 3.91 \\
\hline The state of the signage made travel easy & $\begin{array}{l}\text { Ave. Likert } \\
\text { score }\end{array}$ & 4 & 3.73 & 3.3 & 3.86 & 4.3 & 4.2 \\
\hline $\begin{array}{l}\text { It was easy to get to [destination] for my } \\
\text { visit }\end{array}$ & $\begin{array}{l}\text { Ave. Likert } \\
\text { score }\end{array}$ & 4 & 4.27 & 3.9 & 4.4 & 4.7 & 4.33 \\
\hline \multicolumn{8}{|l|}{ Environment sub-indicators } \\
\hline I found [destination] to be clean & $\begin{array}{l}\text { Ave. Likert } \\
\text { score }\end{array}$ & 4.2 & 4.45 & 4.7 & 4.8 & 4.7 & 4.42 \\
\hline I was bothered by noise & $\begin{array}{l}\text { Ave. Likert } \\
\text { score (-ve) }\end{array}$ & 2.22 & 4 & 2.1 & 1.4 & 1.3 & 1.44 \\
\hline I was bothered by solid waste & $\begin{array}{l}\text { Ave. Likert } \\
\text { score (-ve) }\end{array}$ & 1.78 & 2.27 & 2.2 & 1.1 & 1.3 & 1.71 \\
\hline $\begin{array}{l}\text { The state of the natural environment was } \\
\text { good }\end{array}$ & $\begin{array}{l}\text { Ave. Likert } \\
\text { score }\end{array}$ & 4.5 & 4.45 & 4.5 & 4.6 & 4.8 & 4.45 \\
\hline $\begin{array}{l}\text { [Destination] has an interesting and } \\
\text { varied landscape }\end{array}$ & $\begin{array}{l}\text { Ave. Likert } \\
\text { score }\end{array}$ & 4.2 & 3.73 & 4.8 & 4.7 & 4.7 & 4 \\
\hline \multicolumn{8}{|l|}{ Service sub-indicators } \\
\hline The quality of the local cuisine was good & $\begin{array}{l}\text { Ave. Likert } \\
\text { score }\end{array}$ & 3 & 3 & 4.22 & 4.7 & 4.6 & 4.5 \\
\hline The quality of accommodation was good & $\begin{array}{l}\text { Ave. Likert } \\
\text { score }\end{array}$ & 3.78 & 3.82 & 4.4 & 4.7 & 4.3 & 5 \\
\hline The level of service provided was high & $\begin{array}{l}\text { Ave. Likert } \\
\text { score }\end{array}$ & 4.1 & 3.8 & 4.56 & 4.8 & 4.4 & 4.13 \\
\hline Service staff was competent and helpful & $\begin{array}{l}\text { Ave. Likert } \\
\text { score }\end{array}$ & 4.22 & 3.91 & 4.8 & 4.9 & 4.5 & 4.36 \\
\hline \multicolumn{8}{|l|}{ Safety sub-indicators } \\
\hline I felt safe and secure during my visit & $\begin{array}{l}\text { Ave. Likert } \\
\text { score }\end{array}$ & 4.3 & 4.36 & 4.7 & 4.8 & 4.9 & 4.5 \\
\hline
\end{tabular}

Source: Author's estimations. 


\section{Cross-Case Analysis of a Selected Environmental Issue}

\section{Issue 10: Energy Management}

All tourism establishments require energy to conduct their business. Energy management is a key component of the environmental sustainability of CBE ventures.

\section{Indicator 10.1: Per Capita Energy Consumption (Per Person Per Day)}

The average monthly energy consumed for each of the CBE ventures was calculated. Across all the cases investigated there was a high dependence on Liquid Petroleum Gas (LPG) and diesel. This dependence was further exacerbated where CBE ventures did not have access to grid electricity. The energy consumption for the two CBE ventures offering camping facilities (Aba-Huab (individually operated) and Kaziikini (community-operated)) was considerably lower than the ventures offering built accommodation (Table 7). This is to be expected as the tourists who camp supplement their energy needs through their own resources and are not as dependent on the venture for filling all their energy needs.

In order to have a comparable per capita energy use, the total energy of each CBE venture was divided by the average monthly overnight visitors to calculate an average per capita consumption of energy per day. This reveals interesting results.

- Damaraland Camp (formal joint venture) had the highest per capita energy use at $132.35 \mathrm{kWh}$ per visitor per day. This was despite the exceptional energy-saving measure implemented in all of the tourist accommodation units. The most important contributing factor to this high per capita energy use is the large amount of diesel and LPG which is consumed by the venture. The camp has no grid electricity (with the exception of a borehole pump four $\mathrm{km}$ away from the camp) and as a result has to generate the majority of the energy needs though a diesel powered generator. The large distances covered daily by the game drive vehicles also contribute significantly to the high diesel consumption.

- Tembe Lodge (triple joint venture) had the second highest per capita energy consumption, at $69.54 \mathrm{kWh}$ of energy per day; the third highest was !Khwa ttu (organization operated) which consumed $51.26 \mathrm{kWh}$ per day, then Kaziikini (community-operated) at $18.53 \mathrm{kWh}$, Malealea (informal joint venture) at $17.15 \mathrm{kWh}$ and the lowest energy consumption at Aba-Huab (individually operated) at $9.96 \mathrm{kWh}$ of energy per capita per day. (AbaHuab's energy consumption however excludes grid electricity as no data for grid electricity was available resulting in the lowest per capita energy.)

- When the daily per capita energy consumption results are compared with international benchmarks as proposed by the International Tourism Partnership (ITP), as shown in Table 6, it is clear that five of the CBE ventures may be classified as having high per capita energy consumption, with the only exception being Aba-Huab. However, if the grid electricity use of Aba-Huab was known it is likely that this CBE venture may also be classified as high. 
Table 6. Daily Per Capita Energy Consumption Benchmarks at Hotels (in $K w h)$

\begin{tabular}{|c|c|c|}
\hline Excellent & Satisfactory & High \\
\hline Less than 11.3 & $11.3-13.5$ & More than 13.5 \\
\hline
\end{tabular}

Source: Adapted from ITP 2008, p. 75.

Although the energy consumption may be classified as high in terms of the proposed ITP benchmarks, one fundamental difference may be noted between CBE ventures and hotels on which the benchmark is based. The nature of the $\mathrm{CBE}$ ventures that were investigated is such that at each $\mathrm{CBE}$ venture the employees and their families also live on the tourism premises and are dependent on the tourism venture for their energy needs. At the majority of the ventures all the staff and their immediate family members reside on the tourism venture premises. In order to provide a more accurate per capita energy use at the CBE ventures the total energy consumption should in fact be divided by the sum of the overnight visitors and the staff and their dependants living on the tourism premises. Although this study did not attempt to establish the total number of community members (staff and their dependants) living on the tourism premises it is important that future studies establish the total number of community members living on the tourism premises in order to get a clear indication of the energy use per capita for the CBE ventures.

Table 7. Summary of Cross-Case Responses Relating to Issue 10: Energy Management; Issue 10.1: Per Capita Energy Consumption (Per Person Per Day)

\begin{tabular}{|c|c|c|c|c|c|c|c|}
\hline \multicolumn{2}{|l|}{$\begin{array}{l}\text { Issue 10: Energy } \\
\text { management }\end{array}$} & \multirow{2}{*}{\begin{tabular}{|c|}
$\begin{array}{c}\text { Individually } \\
\text { operated }\end{array}$ \\
$\begin{array}{c}\text { Aba-Huab } \\
\text { Campsite }\end{array}$ \\
\end{tabular}} & \multirow{2}{*}{\begin{tabular}{|l|}
$\begin{array}{c}\text { Community } \\
\text {-operated }\end{array}$ \\
$\begin{array}{c}\text { Kaziikini \& } \\
\text { Shandreka }\end{array}$ \\
\end{tabular}} & \multirow{2}{*}{\begin{tabular}{|c|}
$\begin{array}{c}\text { Informal } \\
\text { joint } \\
\text { venture }\end{array}$ \\
Malealea \\
Lodge
\end{tabular}} & \multirow{2}{*}{\begin{tabular}{|c|}
$\begin{array}{c}\text { Formal joint } \\
\text { venture }\end{array}$ \\
$\begin{array}{c}\text { Damaraland } \\
\text { Camp }\end{array}$ \\
\end{tabular}} & \multirow{2}{*}{\begin{tabular}{|c|}
$\begin{array}{c}\text { Triple } \\
\text { joint } \\
\text { venture }\end{array}$ \\
$\begin{array}{c}\text { Tembe } \\
\text { Lodge }\end{array}$ \\
\end{tabular}} & \multirow{2}{*}{$\begin{array}{c}\begin{array}{c}\text { Organ. } \\
\text { Operated }\end{array} \\
! K h w a t t u\end{array}$} \\
\hline & & & & & & & \\
\hline \multicolumn{8}{|c|}{ 10.1 Per capita energy consumption (per person per day) } \\
\hline \multicolumn{8}{|c|}{ Average monthly energy use } \\
\hline $\begin{array}{l}\text { Liquid Petroleum } \\
\text { Gas }\end{array}$ & $\mathrm{kWh}$ & 3943 & 1971 & 16428 & 5257 & 11171 & 1971 \\
\hline Diesel & $\mathrm{kWh}$ & 1867 & 1899 & 6402 & 34678 & 8963 & 4802 \\
\hline Petrol & $\mathrm{kWh}$ & 2850 & 0 & 1900 & 0 & 0 & 1425 \\
\hline Grid electricity & $\mathrm{kWh}$ & Unknown & 0 & 0 & 529 & 3362 & 16815 \\
\hline Solar power & $\mathrm{kWh}$ & 0 & 19 & 97 & 213 & 19 & 97 \\
\hline Total & $\mathrm{kWh}$ & 8660 & 3889 & 24827 & 40677 & 23515 & 25110 \\
\hline $\begin{array}{l}\text { Average monthly } \\
\text { overnight tourists } \\
\text { (indicator } 8.1 \text { ) }\end{array}$ & No. & 869.60 & 209.87 & 1447.62 & 307.35 & 338.13 & $489.81 * *$ \\
\hline $\begin{array}{l}\text { Energy use per } \\
\text { overnight visitor }\end{array}$ & $\mathrm{kWh}$ & $9.96 *$ & 18.53 & 17.15 & 132.35 & 69.54 & $51.26 * * *$ \\
\hline
\end{tabular}

Source: Author's estimations. 
Although this study does provide some form of benchmark against which other CBE ventures can measure their energy use, it is important to realize that additional research is necessary before a more appropriate per capita energy benchmark can be established.

\section{Assessment of the Utility of the Evaluation Framework}

The framework has proved valuable in collecting information on the sustainability of the case studies investigated within a relatively short time period. The evaluation framework has succeeded in establishing areas of present and possible future concern that need to be managed in order to ensure the long-term sustainability of the investigated ventures. In order to increase the utility of the framework and the associated results obtained, a number of improvements and additions are recommended that would improve both the quality of the data collected and ensure that data collected across case studies may be standardized to facilitate comparison and benchmarking in future.

\section{Recommendations Relating to Social Issues and Indicators}

The population density of the surrounding communities should be established wherever possible to assist in the quantification and contextualization of the results in terms of the employment opportunities and the effects that tourism may have on households in the community. Issue 2 : Indicator 2.2; Question: "Does tourism employ local youth?" should be rephrased or restated in future research to find out whether only young people are employed or both young and old. This indicator will provide an indication of whether there are income earning imbalances in the community where the young people have all the economic power or whether the economic power is spread evenly throughout the community. Issue 5: Indicator 5.1: Personal, household and community benefits should be defined not merely as employment opportunities or money received. Other responses relating to aspects such as receiving education; infrastructure and services; and food and clothing should also be elicited.

\section{Recommendations Relating to Economic Issues and Indicators}

Although the most significant aspects relating to the identified economic issues and indicators were established, it is felt that additional economic issues and their associated indicators need to be included in future studies. Aspects that could be included relate to the income earned by all the staff members employed (by gender) at various levels throughout the tourism enterprise. An attempt should also be made to establish the possible economic multiplier effects within the community. 


\section{Recommendations Relating to Environmental Issues and Indicators}

The total number of community members (staff, their families and other community members) living on the tourism premises needs to be established in order to accurately calculate the per person per day use of energy and consumption of water as well as the per capita volume of waste produced. This will facilitate better cross-case comparisons and more applicable and compatible benchmarks. This recommendation affects Issue 10: Indicator 10.1, Issue 11: Indicator 11.1, and Issue 14: Indicator 14.1. Issue 12: Indicator 12.1: Micro-determinants such as aluminium, antimony, arsenic, cadmium, chromium, cobalt, copper, cyanide, iron, lead, manganese, nickel, mercury, selenium and vanadium, as well as organic determinants such as dissolved organic carbon, trihalomethanes and phenols, should also be included in future studies (Standards South Africa 2006). The inclusion of these water quality indicators will however have significant cost implications. Issue 15: Indicator 15.1: In the case of CBE ventures the use intensity should be measured in area per tourist rather than in tourists per square metre as usually accepted. The CBE ventures under investigation generally cover a much larger surface area and the use intensity is not as high as, for example, congested beaches where tourists per square metre is more relevant.

\section{General Recommendation on the Utility of the Evaluation Framework}

An additional recommendation that would further improve the utility of the evaluation framework once the abovementioned amendments have been made, is to repeat the monitoring investigation on the same case studies so as to monitor the changes that have occurred over time. This may indicate positive improvements and changes that may have occurred since the previous investigation. New issues that were not found in this study may also be found that may need to be addressed in the future.

The constructed evaluation framework proved useful for the monitoring of the sustainability of the six CBE ventures under investigation. It should be remembered that every specific $\mathrm{CBE}$ venture may have unique aspects and issues which affect its sustainability. The framework therefore only serves as a generic framework which may be applied across various types of CBE ventures-specific adaptations to specific sites will be necessary.

\section{Conclusions}

The constructed evaluation framework provides a valuable tool by which the sustainability of community-based ecotourism ventures may be measured. Although the framework proposes a generic means by which the sustainability of $\mathrm{CBE}$ ventures may be determined worldwide, it is foreseeable that the framework should be adapted when applied in different contexts. The framework, with minor adaptations and additions, should also be reapplied continuously over time to the same case studies. This will lead to the fine- 
tuning of the framework and it will also serve as a means to establish which changes in sustainability may have occurred since the last application of the framework. Each new and repeated application of the framework will lead to a series of recommendations relating to aspects which need attention in order to improve the sustainability performance of the investigated venture.

Although the evaluation framework was developed in a top-down approach, it is important that communities be enabled to take ownership of such evaluation frameworks in the future. The associated results from the field testing delivered a useful tool and valuable beginning point to encourage community-based ecotourism ventures to start on the adaptive learning process of sustainability indicator development and use. The framework should not be seen as a rigid, fixed framework but rather as an adaptable tool which can be amended continuously to fit local conditions and circumstances. The framework provides a method of monitoring the sustainability of communitybased ecotourism ventures.

It is expected that tourist arrivals will increase to 1.6 billion by the year 2020 (WTO 1998). Over and above the increase in arrivals, tourists are expected to become more discerning in their search for quality and value for money. Tourists are also expected to become increasingly conscious of their impacts on the environment and as a result will demand more sustainable tourism products. An increased demand for nature-based products is also expected (Siegfried 2002). Community-based ecotourism ventures are well positioned to fulfil the demand arising from these changing trends in tourism demand.

\section{References}

Dixey, LM (2008) The unsustainabilty of community tourism donor projects: Lessons from Zambia. In A Spenceley (ed.). Responsible tourism: Critical issues for conservation and development. London: Earthscan, 323-342.

Epler Wood, M (2002) Ecotourism: principles, practices and policies for sustainability. Paris: United Nations Environmental Programme.

Fennell, DA (2003) Ecotourism: an introduction. (Second edition). London: Routledge.

Goodwin, H \& Santilli, R (2009) International Centre for Responsible Tourism. Community based tourism: A success? Retrieved August 22, 2014, from: http://www.icrtourism.org/documents/op11merged.pdf.

Hart, D (2015) Indicators of sustainability. Retrieved April 16, 2015, from Sustainable Measures website: www.sustainablemeasures.com/indicators.

ITP-International Tourism Partnership (2008) Environmental management for hotels: The industry guide to sustainable operation. (Third Edition) London: ITP.

Johnson, PA (2001) Status of NRBCT initiatives in Southern Africa and recommendations on sustainability. Gaborone: Regional Centre for Southern Africa, United States Agency for International Development (USAID).

Keyser, H (2009) Developing tourism in South Africa: Towards competitive destinations. Cape Town: Oxford University Press. 
Magakgala, M (2003) Main streaming protected areas. In GI Gowan, J Yawitch \& M Swift. (Eds.). Strategic innovations in biodiversity conservation: the South African experience. Pretoria: Department of Environmental Affairs and Tourism.

Magome, H (2003) Protected areas and community participation in South Africa: challenges and opportunities. In J. Ledger (Ed.). Walking with nature: protected areas, people and prosperity. Johannesburg: HIS.

Mearns KF (2010) The sustainability of community-based ecotourism in southern Africa. Unpublished Doctoral thesis, Portsmouth: University of Portsmouth.

Okech RN (2009) Developing urban ecotourism in Kenyan cities: A sustainable approach. J. Ecol. Nat. Environ., 1(1): 001-006.

Scheyvens, R (1999) Ecotourism and the empowerment of local communities, Tourism Management, 20, 245-249.

Siegfried, R (2002) Keeping the rainbow. Cape Town: PPD Publishing.

Standards South Africa (2006) South African national standard - Drinking water (SANS 241:2006 Edition 6.1). Pretoria: Standards South Africa.

The International Ecotourism Society (TIES) (2015) Ecotourism. Retrieved March 2015, from The International Ecotourism Society website: www.ecotourism.org.

WTO-World Tourism Organisation (1998) Tourism 2020 Vision. Madrid: World Tourism Organisation.

WTO-World Tourism Organisation (2004) Indicators of sustainable development for tourism destinations: a guidebook. Madrid: World Tourism Organisation.

WTO-World Tourism Organisation (2007) Sustainable tourism indicators and destination management: regional workshop Kolasin, Montenegro, 25-27 April 2007. Madrid: World Tourism Organisation. 